\title{
Transporting the deceased by the wheeled cart in the Greco-Roman Tombs
}

\author{
Wahid Omran ${ }^{1}$ \\ Assistant Professor at Guidance Department \\ Faculty of Tourism and Hotels- Fayoum University
}

\section{ARTICLE INFO}

Keywords:

the deceased- the mummy- the funeralthe afterlife.

\section{(JAAUTH) Vol.17, No2, (2019), pp. 32-49.}

\begin{abstract}
Äbstract
This paper discusses the process of transporting the mummy of the deceased to his tomb in the Graeco- Roman period, through only the scenes which are depicted in the tombs of the Graeco- Roman period in Egypt. It investigates the arrangements and activities of this first important step for the transfiguration of the deceased in the hereafter. The wheeled cart is the main transportation mean of the mummy in the Graeco- Roman tombs, therefore, the paper studies and analyzes also the depictions of the transportation scenes in the tombs, and the model of the transporting cart.
\end{abstract}

\section{Introduction}

The ancient Egyptians' beliefs concerning the transforming of the deceased into a glorified spirit in the afterlife and the practice of the burial itself date back to the prehistoric periods ${ }^{1}$. Model boats have been discovered in Badarian, Naqada I and Nagada II onward burials ${ }^{2}$ depicting the means by which the deceased were conveyed to the cemetery. In some cases, a star is depicted in the boat to guide the dead on his voyage to the afterlife ${ }^{3}$. Barks were also buried adjacent to the Old Kingdom tombs at Saqqara, Abu Roash, Helwan, Abusir and Abydos ${ }^{4}$. Depicted model sacred barks of the gods are borne aloft shoulders of priests in the temples, a loftier version of drawing boats along on sledges suggested by the fact that two or more horizontal carrying poles commonly support a sledge upon which the bark sits 5 .

In ancient Egypt, transporting the mummy through the land of the living was a major feature of the funeral, most probably symbolic for crossing the Nile from east to west, the land of the dead. In Ancient Egypt, transporting the mummy to the tomb was a major event to carry out and depict the visual last sight of the dead. The tomb was designated to be a dwelling place of the afterlife, it visualizes the dead social status, their cultures and funerary beliefs, thus, it was a major expense of the deceased ${ }^{6}$, whereas houses meant to be inhabited for only a person's lifetime. The physical location of the tomb was important for the prestige of the deceased. Some tombs were grouped in specific areas because the tomb owners shared the same profession. Other owners received their tomb sites as a reward from the king ${ }^{7}$.

Herodotus described the mourning actions by the dead relatives during the funeral; the female 'smear their heads with dust, and sometimes also the face, and then they leave the corpse in the house and themselves wander through the town and beat their breasts with garments girt up and revealing their breasts ..... And the males beat their breasts separately, these too with 
their garments girt up ${ }^{9}$. Professional mourners participate in the wealthy dead burial ${ }^{9}$, they recited laminations that helped to revivify the deceased ${ }^{10}$.

The pilgrimage to Abydos and the funeral of the deceased was obvious in its actions by the time $^{11}$. The wheel is known in ancient Egypt from the Old Kingdom at the latest ${ }^{12}$. The mummy was mounted either on a sledge or a wheeled cart drawn by bulls to make it easier to transport over sand. The wheeled cart was the main transportation's mean for the mummy since the New Kingdom. It was developed by the time, in place of usual sledge ${ }^{13}$. In rare instance, the cart mounted the sledges have transverse beams beneath the runners, which it would be more probable for the wheeled vehicle that carries the sledge ${ }^{14}$.The best known wheeled cart is the small gold and silver model from the $18^{\text {th }}$ Dynasty tomb of Queen Ah-hotep II ${ }^{15}$ at Dra' Abu el-Naga in West Thebes without studded tiers ${ }^{16}$.

The wheeled vehicle, cart, wasn't only used for religious procession, but it was used also in general, by the New Kingdom at least ${ }^{17}$. The wheeled cart and sledges were also used for hauling a heavier harvest through the desert or the outer regions, most of the carts known of the New Kingdom were used for the transport of freight and loads, not for people ${ }^{18}$. Water or oil was put under the sledge for easier and faster movement. Except for chariots and sledges, there is only rare evidence for the use of wheeled carts and wagons as a means of transport, probably because of the climatic sandy ground fiction increases; moreover, the wheels were not practical during the annual inundation ${ }^{19}$.

In ancient Egypt, transporting the mummy through the east land of the living to the west land of the dead was a major feature of the funeral as the first step for following Osiris in the Underworld. During the Ptolemaic- Roman period, the deceased is depicted in his tomb on the wheeled-cart evoking assimilation with Osiris and Harpocrates as they are the gods who possessed a bark-carriage ${ }^{20}$. An inscription in the temple of Esna dates to Domitian's period, mentions a cart "Wryt" of good Chnum with a marvelous velocity used by the god to reach Chemmis ${ }^{21}$,probably from Esna ${ }^{22}$, and is mainly related to his solar character.

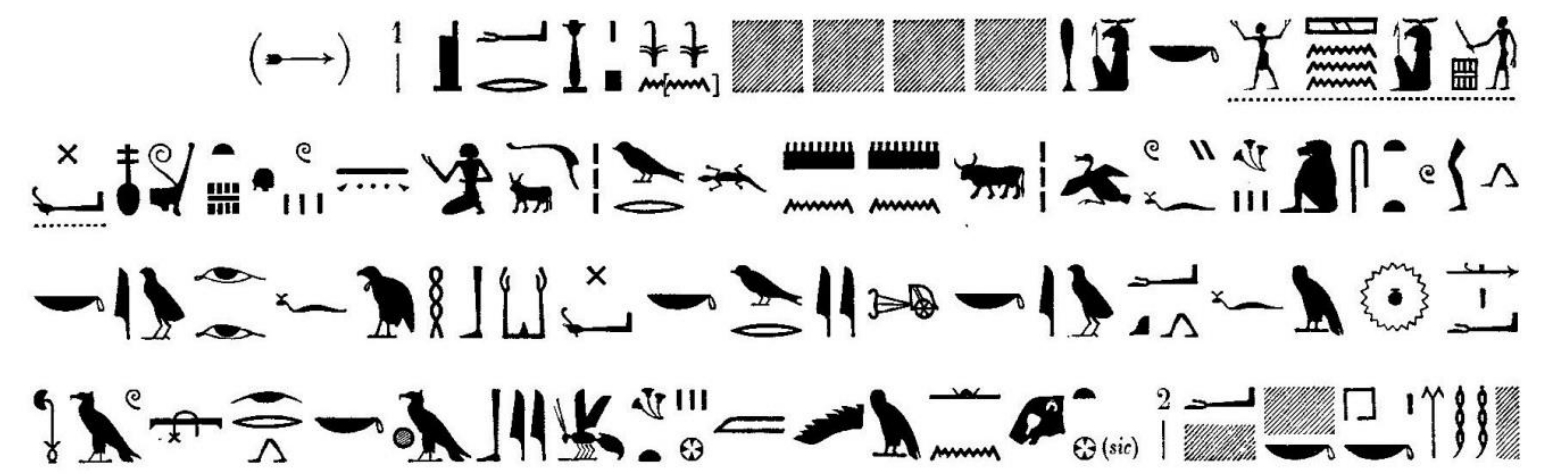

"Your Majesty Khnum-The Good Shepherd of the inhabitants of the Earth, the great head of herds, rich in cattle, is a swamp of papyrus, or you walk to contemplate it. You splice your cart so as to penetrate it in one night, and you reach Khemis in the escape of a moment... "23

A late Ptolemaic mummy breastplate depicts the stages of the deceased's transformation in the afterlife through three action starts with the mummy's transportation in a boat, the embalming and then the judgment of the dead. Above these vignettes is a winged scarab alluding to the newborn sun and the scarab on the corpse of Osiris ${ }^{24}$. 
According to the Classical Hermetic treatises ${ }^{25}$; the world is seen as a chariot, the equilibrium of which is guaranteed the sun, and also described Horus of Edfu 'Helius' (Apollo) as king and falcon, and referred to the horses of the sun ${ }^{26}$. Riding the Greek deceased by horse-chariot well known in the Greek methodology ${ }^{27}$. On gems the solar boat ${ }^{28}$, occurs mainly connected with the sun child 'Harpocrates', but the quadriga of 'Hellius' was rather popular too ${ }^{29}$. Also, the ancient Greek belief illustrated also the ferryman Charon, who conveys the souls to the Underworld ${ }^{30}$, similar to the ancient Egyptian custom, the ferryman conveyed the dead across the rivers of the underworld to ensure that the deceased could pay, it was customary to place a coin in the mouth or hand of the corpse before burial. For Egyptians, it was not a radical step, though some was acceptable in their conception of the afterlife for centuries ${ }^{31}$; especially since the coin was later a common feature well ${ }^{32}$. A few Ptolemaic mummy cases with coins in their hands or mouth are documented, as those found in the burials discovered in the forecourt of the pyramid temple of Menkaure at $\mathrm{Giza}^{33}$, while the majority have been found in the Roman period as well to ferry across the Sty $x^{34}$. According the Greek mortuary context, the psychopompos attribute of Hermes gets him to lead the dead to the skiff that traverses the river Styx, and to Charon its navigator, Hermes also -by his kerykeion 'cauceus'- harrows the underworld at will ${ }^{35}$.

\section{The Funeral}

The afterlife in the Ptolemaic-Roman Egypt was mainly focused on the Re-Osiris syncretism, therefore, the deceased's hope to join the solar-Osirian circuit resting in peace with Osiris in the netherworld, and traveling in the day and night barks of the sun god. The two gods are inseparable; the terrestrial and celestial gods of the afterlife ${ }^{36}$. Therefore, the tomb was a major expense of the deceased because it was the dwelling of their afterlife under the protection of Osiris and Re, and the mummy was a symbol and guarantor not for death but for life in the hereafter as well.

Multiple burial activities were undertaken through the funeral. Embalming the mummy in the 'wabet-workshop' most probably attached to the cemetery, the body was released from the workshop and then rested in a coffin. Special spells known as 'sakhu-glorification spells' ${ }^{37}$ were recited during the Ptolemaic period in the embalming place prior to the burial ${ }^{38}$. As the mummy of Osiris was ferried by the neshmet-bark, therefore, the deceased evokes his mummy being transported upon a bark in a great procession followed by his relatives and friends, grave goods, offering- bearers as well as professional female mourners. Pulling the sarcophagus to the tomb was usually done by the relatives and the friends of the deceased, as illustrated by the Nine Friends ${ }^{39}$ in the tomb of Tutankhamun ${ }^{40}$. Once the procession arrived at the tomb, the mummy was stood upright, and then the priests performed the 'Opening of the Mouth' to restore the deceased's ability to see, speak, hear, and taste ${ }^{41}$. Furthermore, a sem-priest, most probably the eldest son, purified the mummy and the statue of the deceased as well. Other sequence of funerary rituals were enacted including the ' $m u$ ' dance to help ferry the deceased across water to the afterlife ${ }^{42}$, the funeral banquet took place ${ }^{43}$, and finally, the tomb was sealed $^{44}$.

From the New Kingdom onwards, the choachyte-priest in Graeco- Roman Egypt still in charge of the tomb ${ }^{45}$, who had the title $w 3 h-m w . w$ 'pourer of the water'. He was engaged by the family of the deceased to perform the role of the son(s) in his care of the dead. One of his main duties was to sell the tomb in the case of the family that did not yet have a tomb for the burial, as well as preparing for the various funeral activities including the mummification, storing and transporting the mummy, and furnishing the tomb. In some cases, the 'grave-digger' charged in transporting the mummy to the tomb $^{46}$. After the funeral, the choachyte took care of the deceased and made food offerings in the 
tomb $^{47}$, the 'overseer of the necropolis tax' was incurred by the choachyte as well as masking the mummified dead with divine face of Osiris.

During the mummy transportation, another helper, known in Greek as nekrotophos, who hasn't yet an Egyptian equivalent, was also possibly helping the choachyte for shipping the mummy to the necropolis. Therefore, the choachyte himself or the family of the deceased presumably engaged the nekrotophos as one of the procedures for the funeral accounts ${ }^{48}$.

In Roman Egypt, before the burial, mummies were kept on display in houses for some time after death to participate in family life for the actual burial ${ }^{49}$. Diodorus also confirmed the ancient Egyptian custom of keeping the mummies in the house, and they have to afford to construct a new chamber in their houses to receive the mummy as a temporary funerary residence for a while before their departure to the necropolis, the final destination ${ }^{50}$. The later custom of keeping the mummies of the deceased in the house can only be derived from the Egyptian ancestral cult ${ }^{51}$, which was widely known from the New Kingdom ${ }^{52}$. The fisherman Aigialeus preserved the dead body of his wife 'in an Egyptian way' to have her around for longer, to talk to her, eat and sleep with her and so on ${ }^{53}$. The mummies were kept in houses to allow the deceaseds' families and relatives and friends to watch, they gather in the courtyard of the house for temporary abode of the deceased, are ready to attend the burial and share its costs. In Graeco- Roman period, some mummies were kept in the houses for a long period awaited until the arrangements of his funeral and the preparation of his tomb. The mummy label of Takhenmet, daughter of Petarsmoutheus, recorded that a year and four months that the mummy was kept in the house before the burial ${ }^{54}$. Also, in the Roman period, the goldsmith Besa, asked his friend Eidos to 'fetch the body of my father and keep it safe until I sail back, God willing, for the funeral' ${ }^{55}$. This longtime of housing the mummy helps to ease the transformation of the deceased from his living life to his afterlife ${ }^{56}$. In some cases, the choachytes also used their house to keep mummies awaiting burial $^{57}$.

After the burial, family and friends of the deceased visited the tomb on certain days as part of cult of the dead and ate meals in the tomb $b^{58}$. Funerary banquet meals could be celebrated in Roman Egypt on both birth and death days of the deceased ${ }^{59}$, as the tri-clinum dining hall of Kom elSchouqafa suggests that banquets were held by family members, who visit the tomb at or may have dined near the tomb in the necropolis certain times of year, as in Tuna El-Gebel ${ }^{60}$. Therefore, the choachytea stocked utensils necessary for the service in order to provide for the families during visiting the tombs ${ }^{61}$. All of these actions contributed in a magical way to the protection of the dead on their dangerous way into the other world ${ }^{62}$ and transformation into a new being. The amount of efforts and wealth expanded on the burial of an individual are varying according to his/ her social status ${ }^{63}$.

The mummy shroud BM. Eg. Inv. 30092 shows the transportation of the mummy of the deceased to his tomb. The deceased is depicted in a large scale in the guise of Osiris. On the shroud's feet, just right of Osiris' feet, a four- spoked wheeled cart transports the mummy of the deceased, and a sem-priest is burning incense on the cart's prow. The adjacent vignette illustrates a two wheeled- solar bark carrying the sun god in a circle, and accompanied by two followers; one with the red crown on the prow, while the other wears the white crown on the stern (Fig.1) ${ }^{64}$. It depicts more advanced stage of combination; the bark is not placed on the usual carriage, but is itself wheeled. According to Plutarch, the sun and the moon used as vehicles boats- not chariots ${ }^{65}$. In the Coptic gnostic book Pistis Sophia from the $3^{\text {rd }}$ century $\mathrm{AD}$, the sun is a dragon with its tail in its mouth 'uroboros ${ }^{\text {'66 }}$ who is drawn by four powers in the form of the white horses, while the moon is placed on a boat. 

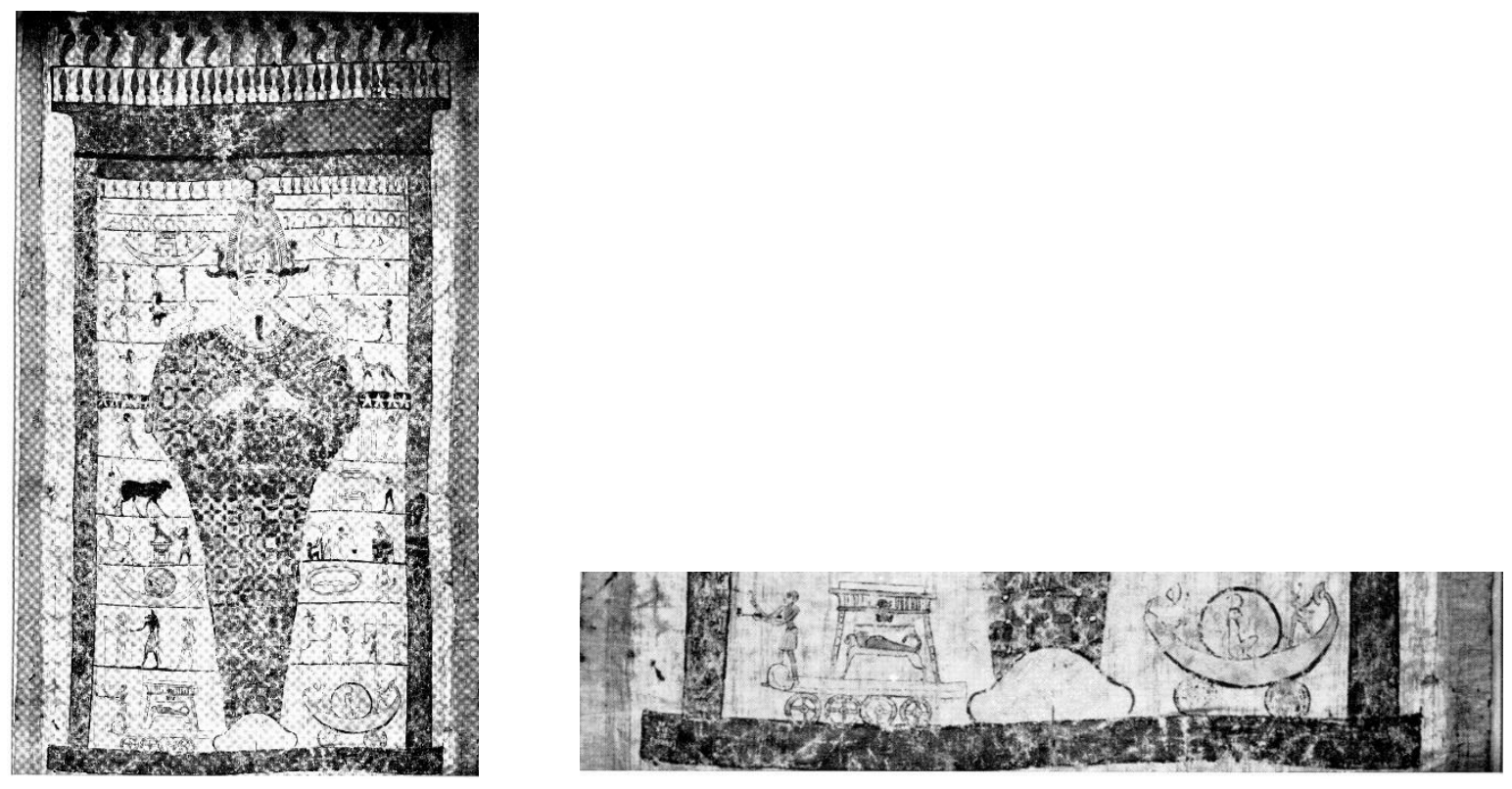

Fig.1. The mummy shroud BM. Eg. Inv. 30092, K. Parlasca, Mumienporträts und verwandte

Denkmäler, 58.2

\section{The mummy's Transportation in the Greco- Roman Tombs}

In the Graeco- Roman tombs, the spoked wheeled cart was the main transportation means of the deceased to his funeral tomb. It was large enough to accommodate the mummy and its coffin within a shrine-shaped catafalque up on a papyrus bark which is used not only to cross the mummy via the Nile to the tomb on the west bank, but also for transcending the nautical as solar boats to traverse the rivers of the Underworld.

Transporting the mummy of the dead by a wheeled cart is frequently depicted on the tombs of Egypt during the Ptolemaic- Roman period such as;

\section{Tomb of P3-di-Wsir 'Petosiris'- Tuna El-Gebel}

The tomb of Petosiris is dated to the early Ptolemaic period, the last quarter of the $4^{\text {th }}$ century $\mathrm{BC}^{67}$, within the period extends from the end of the $30^{\text {th }}$ dynasty 'the Persian rule' and the beginning of the Ptolemaic period. Petosiris, was the high priest of Thot in Hermopolis Magna ${ }^{68}$. The tomb is composed of two rooms, the pronaos and the chapel. It is a family tomb is dedicated to the tomb's builder Petosiris, as well as his father, Neshu, and his brother, Djedthothiufankh, both of whome, like Petosiris, were also priests of Thoth.

Transporting the mummy of Neshu is depicted on the upper most register of the long east wall of the chapel. The funerary conveyance consists of a wheeled cart oriented south, topped by a papyrus bark. It seems highly doubtful that the cart consists of two wheels, the perspective just makes it seem as if there are two rather than four. A bar appears running between the two wheels; it passes behind the felloe of the rear wheel but runs over the felloe and spokes to the hub of the forward wheel as the axle. Each wheel consists of eight-spokes and terminates in a papyrus design where it meets the felloe, the exterior part of the felloe is studded help to overcome the desert sand and shale. An Egyptian catafalque-shrine contains the mummy of Neshu rests on the papyrus bark. A frieze of uraei decorates the shrine. Isis and Nephtys are protecting the mummy shrine. Three males pull the funeral cart along, a 
fourth male priest in front of the cart turns back facing the cart and is burning incense before the shrine. Architectural zigzag lines between the cart's bar and the bottom of the poles support the boat (Fig.2). The adjacent friezes show the other activities and duties of the funeral including the lustration, burning incense, and the offerings. The family, friends, relatives and female mourners are also participating in the procession $^{69}$.
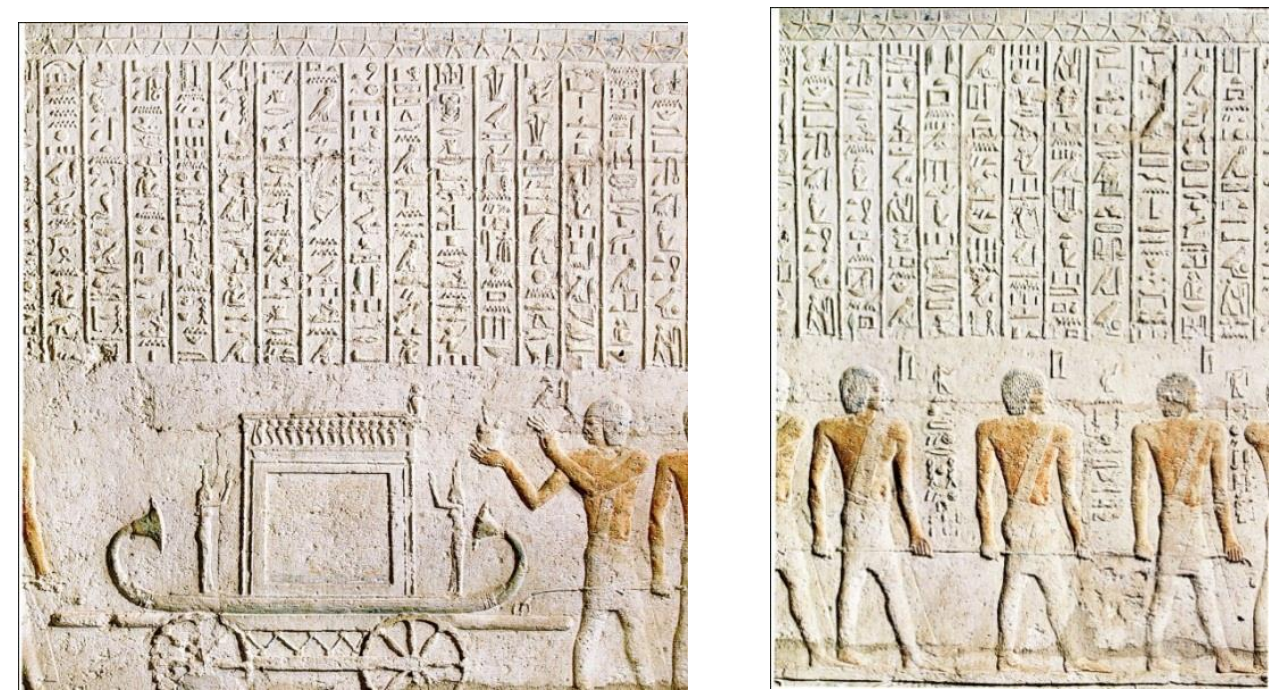

Fig. 2. transporting the mummy of Neshu-Tomb of Petosiris, Tuna El-Gebel

Cherpion, N etal., Le Tombeau de Petosiris, 135, scène 92,5, 6 (GL.81)

Dittmann referred to a similarity between the wheeled funeral wagon in the tomb of Petosiris and another wheeled cart was depicted on the mummy shroud found in S. d'Athanasi collection is now in the British Museum (Fig.3). The solar boat is also topped the wagon, where Isis and Nephtys in the same costume are raising their hands mourning the deceased, and the priest is pulling the cart and burning incense. The $b a$-bird is flying above the mummy ${ }^{70}$.

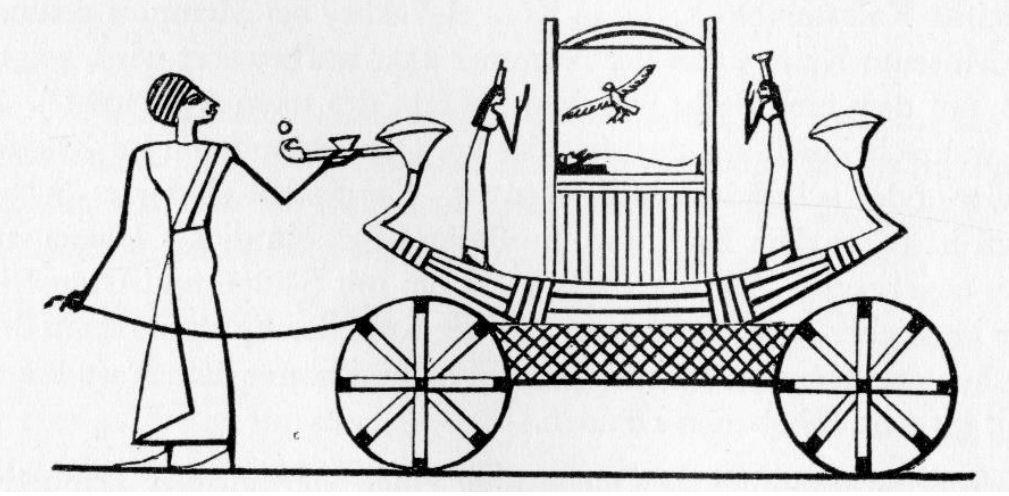

Fig.3. Dittmann, K., Der Segelwagen von Medinet Madi, MDAIK 10, 68, abb.8

Pulling the wheeled cart could be done in different ways; in some cases, the tow-rope is tied not to the sledge or the vehicle but to the bow of the boat being transported ${ }^{71}$. In other cases, the tow rope tied not to a beam between the runners but to the runners themselves, possibly, a metal ring as rollers 
affixed to the runners serves as a purchase to tie the rope ${ }^{72 .}$ The runners of the cart were a team of men $^{73}$, cattle ${ }^{74}$ or both men following cattle ${ }^{75}$, or men and cattle in different ropes ${ }^{76}$. Pouring liquids either milk or water on the course of the cart for slicking the roadway for readier passage of the sledge runners ${ }^{77}$.

\section{Tomb of Si-Amon 'Siamun' in Siwa}

The tomb of Siamun was first published by Fakhry, after its discovery in 1940, dates it to the $3^{\text {rd }}$ century BC, between 400 and $200 \mathrm{BC}^{78}$. Lembke has proposed an early Roman date of the tomb ${ }^{79}$, while Venit suggested that the tomb was probably reused in a later Roman period ${ }^{80}$. The tomb consists of a long, narrow rectangular room, leads to unfinished and undecorated burial chamber. The tomb of Siamun (Man of Amun) lies at Gabel El-Mawta (Mountain of the Dead) at Siwa.

The mummy of Siamuni ${ }^{81}$ was also transported by a similar wheeled cart depicted on the lower register of the east side of the north wall of his tomb. The wheeled cart transports the mummy of Siamun which is lying inside an Egyptian catafalque- shrine being rest upon a solar boat. A frieze of uraei is also decorating the façade of the mummy shrine. Here, the prow of the boat is in the form of a lotus-flower, but its stern is damaged, while the spokes of the wheels are lathe-turned like papyrus stalks $^{82}$, the wheels are also studded similar to the scalloped wheels of the funerary cart of Neshu for better grip in the desert sand and shale. Above, left of the cart is the $b a$-bird, while a tiny figure of Wepwawet is on right. Three standards with images of Horus, Thoth and Anubis are set in front of the shrine on the cart ${ }^{83}$. Two bearded male figures on the lowest register of the adjoining east wall are dragging the cart with a rope, and a another semi damaged male figure behind the cart touches the cart with his right hand while his left hand is clenched in a fist at his chest. Both of the two persons who pull the wheeled cart wear long kilts tied on the waist. Fakhry mentioned that the first has a white skin and is bearded, whereas the second is in red and beardless (Fig.4). Above them, is the celestial cow goddess Mehet-weret, who gives birth to the sun god Re, and the sun disc between her horns.
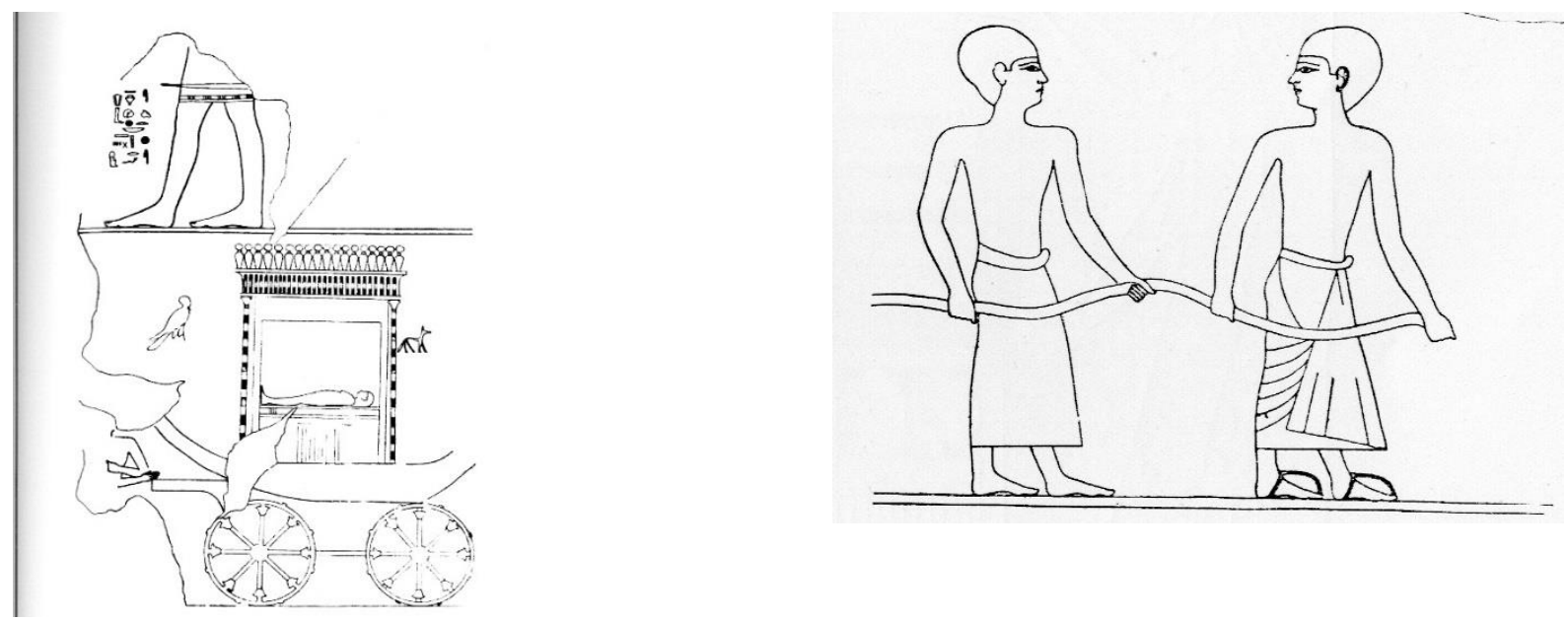

Fig. 4. transporting the mummy of Siamun. Tomb of Siamun- Siwa,

A. Fakhry., Siwa Oasis, 1944, figs. 24, 25

\section{Tomb of P3-di P3stt 'Petubastis' at El-Mazawaka ${ }^{84}$}

Osing dated the tomb on the basis of its style and orthography to the $1^{\text {st }}$ century $\mathrm{AD}^{85}$. Peutubastis served as the priest of Thoth in his single-room tomb ${ }^{86}$. Petubastis served as priest of Thoth at the oasis 
St-w3h. A new style of art depicts twice the wheeled cart with four wheels are quite clear ${ }^{87}$. The first One extends on the south end of the lower register of the east wall extends from left to right, as it is directed from outside towards the inside in the direction of the inner burial-niche of the tomb, contrary to the direction of the figures on the upper frieze of the wall (right to left), while the second depiction is on the lower register of the north wall.

The first scene shows the mummy of Petubastis lying on a lion's bier encased in a catafalque placed on four -wheeled cart, is drawn by four men. Four canopic jars are shown beneath the lion's bed. Directly in front of the cart are two priests; the frontal priest pours a libation while the second holds a censer in his right hand and three twigs on his left hand ${ }^{88}$. (Fig.5)
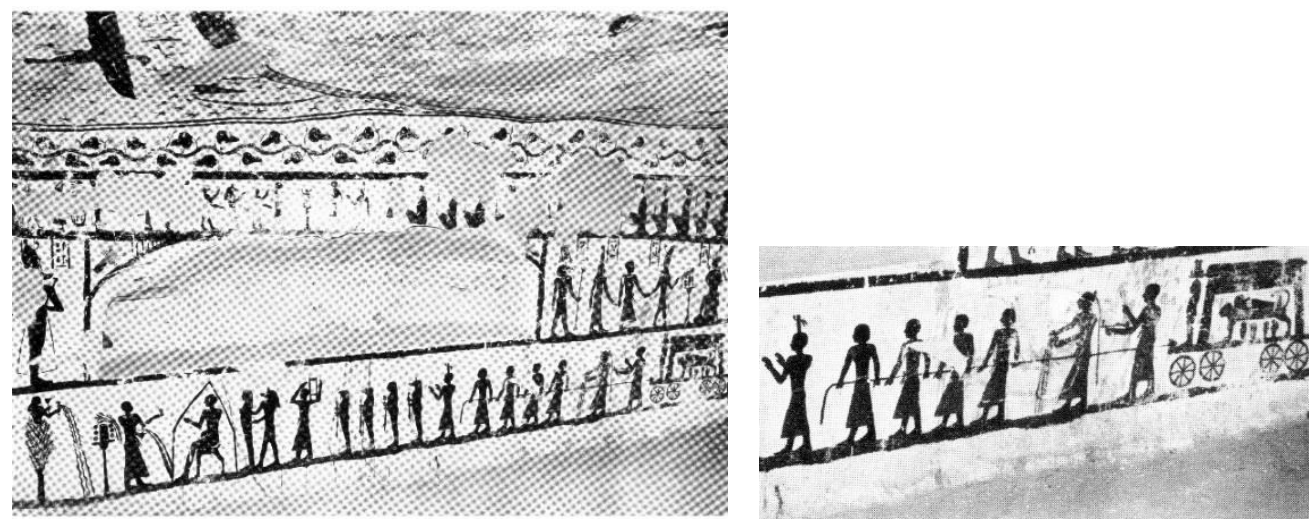

Fig. 5. transporting the mummy of Petubastis, tomb of Petubastis.

J. Osing., Denkmäler der Oase Dachla, taf.21, d

The second funerary procession depicts another four wheeled-cart bears the Petubastis' mummy rests on a lion's bier within a shrine, while the four canopic jars are shown beneath the lion's bed. Two libation bearers are standing before and after the funerary cart, while a priest burns incense with his left hand and pour libations with his right hand walks in front of the cart, and then three men pull the cart. The next vignettes show Petubastis in various funerary conceptions (Fig.6) ${ }^{89}$. As the tomb of Petubastis contains two burial niches are cut in its east and west walls, therefore, the two transportation scenes in this tomb most often suggest that they are connected to Petubastis and one of his family.
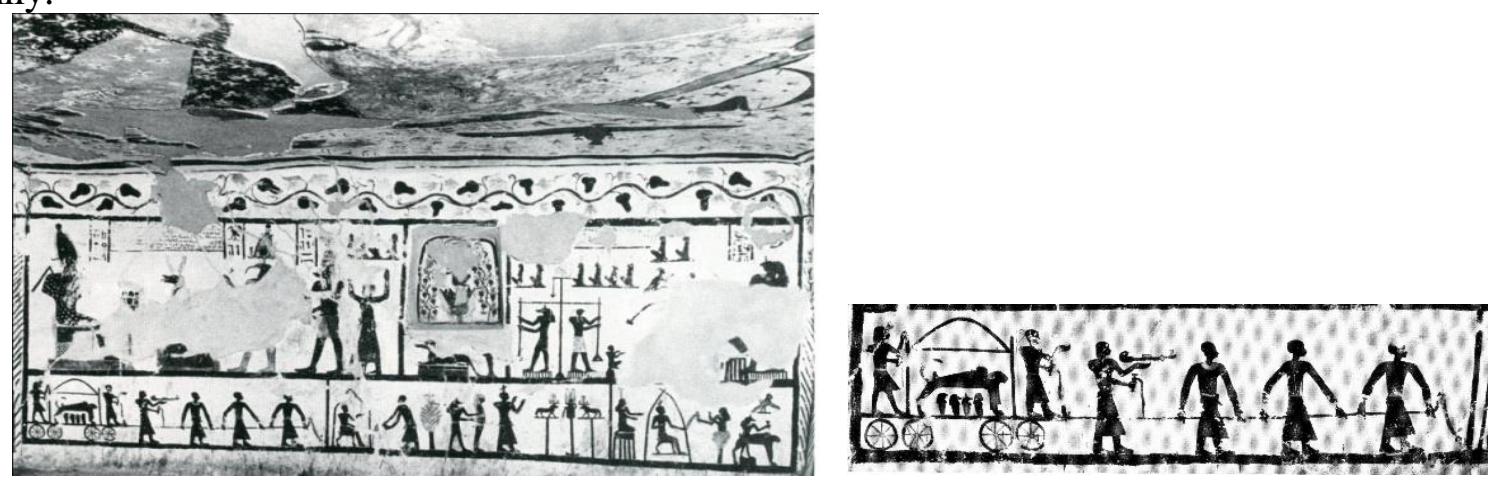

Fig. 6. transporting the mummy of Petubastis Tomb of Petubastis J. Osing., Denkmäler der Oase Dachla, taf. 21. b, 24. a 


\section{Tomb B7, El-Salamuni necropolis ${ }^{90}$}

The El-Salamuni Mountain is the main cemetery of Akhmim during the Ptolemaic- Roman period ${ }^{91}$. Tomb B7 locate on terrace B of the north part of the mountain consists of two chambers with a west façade-entrance.

The funeral transportation of the mummy of the deceased is depicted upon the Eastern wall of the antechamber. It shows the four wheeled cart, its wheels are completely visible similar to that in Petubastis' tomb. The wheels are also studded with eight-spokes to resist the desert sand and shale; especially this tomb that is located upon El-Salamuni Mountain, which requires this type of scalloped wheels. A papyrus bark rests on the wheeled cart bears an Egyptian cavetto-cornice chapel which comprises the mummified Osirian figure of the deceased wearing the nemes headdress and resting upon a lion's bier painted with zigzag decoration. Isis and Nephthys are protecting the mummy. They are standing with up-raised hands in a venerating attitude to the Osirian -form of the deceased. Isis stands at the prow wearing a well fitted green garment, but unfortunately a large part of her head and her supposed traditional emblem are destroyed while her traditional emblem still visible upon her head. Nephthys wears a reddish fitted garment and a recognizable wesekh-collar painted in green, and a great part of her body is also destroyed. Remains of Hieroglyphic texts in front of the two goddesses as well as upon the mummy of the deceased are difficult to read.

Behind Isis, stands an unfinished figure of the desert god Tutu 'Tithoes' in his traditional form as a striding sphinx with long curved tail. He is facing the main entrance of the burial chamber, and wearing the shwty- crown upon a long hair wig are painted in green?!, while the rest of the body is not painted (Fig.7)

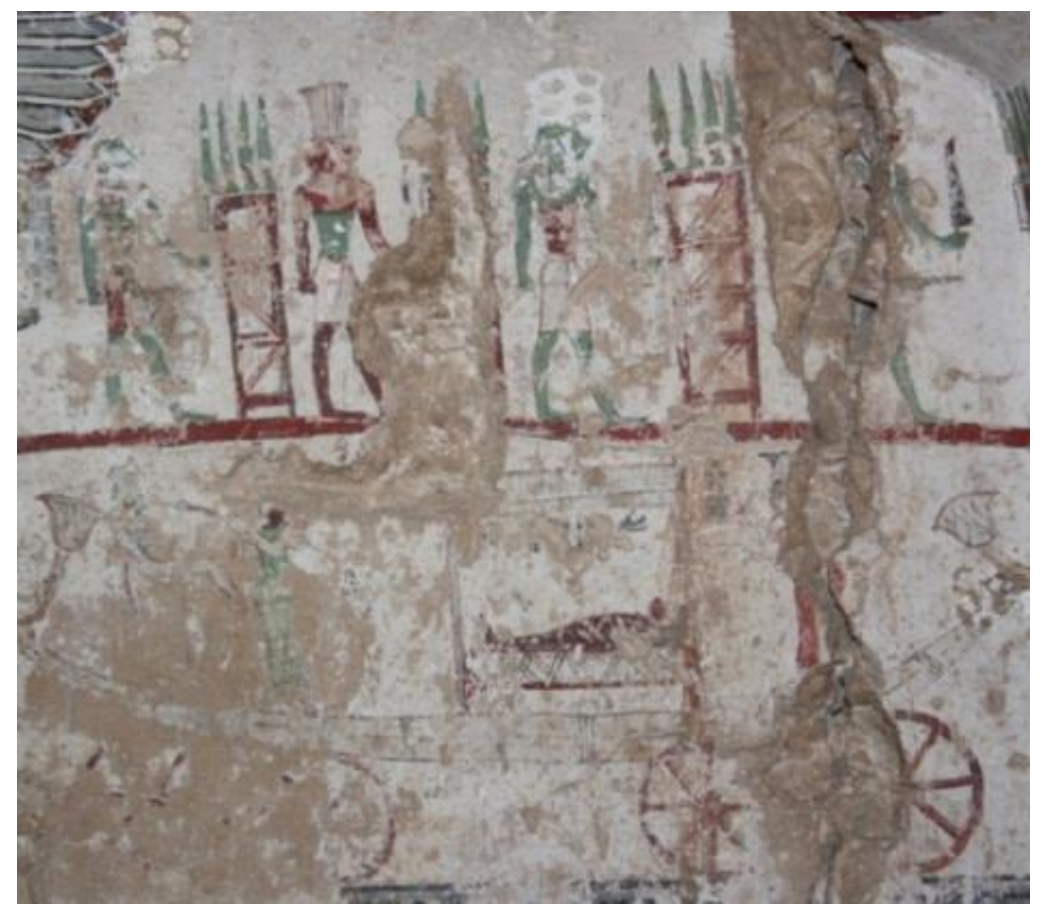

Fig.7. Tomb B7, El-Salamuni, (C) The author 


\section{Commentary}

The funeral in the Graeco- Roman period in Egypt was almost similar to its activities and actions of that in ancient Egypt with the participant of the dead relatives, friends and mourners. The four-wheeled carriage played an important role in the funerary cult during the Ptolemaic-Roman period as mayors as Petubastis or high priests as Si-Amun and Petosiris. All the previous depictions of the wheeled cart are depicted in tombs where their patrons have great social status, which presumably indicate that the deceased in the Tomb B7 of El-Salamuni enjoyed a high rank in the ancient Akhmim/ Panopolis community, as well as may suggests that transporting the mummy by a wheeled cart to the tomb is mainly eliminated for wealthy families during the Greco- Roman period. Also during the GrecoRoman period, the relatives and friends of the deceased are also participating in the funeral. The visual depiction of the funeral is illustrated on the ante and the burial chambers of the tombs as well. The funeral is not a frequent scene in the Graeco- Roman tombs, unfortunately, nothing is known about the program and style of executing the funerary iconography, to determine, if the funeral scene was the preference of the tomb's patron himself, a member of his household, or the artist who is responsible for the tomb's furnishing.

The representation of Isis and Nephtys is a distinctive feature in the funeral bark, it resembles the deceased's attempts to be identified as Osiris ${ }^{92}$. Isis and Nephtys, the sisters of Osiris, were the archetypical mourners in Egyptian mythology, always followed the Osirian-deceased in his bark, they appeared either inside the bark, behind it or stand outside the bark before and behind it $^{93}$.

The mummies of the deceased in these funeral processions were essentially assimilate the deceased with Osiris, this assimilation help the deceased for his justification in the underworld. Only the mummy of Petubastis rests on a lion's bier bed. The lion's head of the bier secures a protection for the deceased. According to the ancient Egyptian beliefs, the lions were guardians of the Eastern and Western horizons, the places of sunrise and sunset ${ }^{94}$. As the lions are connected with the sun, therefore, the lions are connected with death and rebirth, helping the deceased in his rebirth in a similar way to the daily solar cycle ${ }^{95}$. Petubastis was keen to depict the funeral transportation of his mummy of Petubastis on the lion's bier to prove his justification to be a blessed and a transfigured deceased in the hereafter, and under the complete protection of both Osiris and Re.

The procession cart of Tomb B7 is unique, that it records the amazing depiction of god Tithoes in the funeral cart. Tithoes or Totoes was a complex hybrid god who always depicted as a sphinx with different animals' heads ${ }^{96}$. His ritual function inside the tombs is extremely attributed as being the master of the seven demons and genii of Sekhmet, and the son of goddess Neith, the goddess of demons $^{97}$, and he was also assimilated with Seth when he was acclaimed as the vanquisher of Apophis ${ }^{98}$. He is mainly attributed to the Western desert of Egypt as a protective god ${ }^{99}$, therefore, his twice representation in the tomb of Petosiris in El-Mazawaka confirming his guardian characteristic ${ }^{100}$.

The appearance of the bovine-deity Mehet-Weret alongside the funeral wheeled cart in the tomb of Siamun confirms that the deceased in the Graeco-Roman period addressed the solar-Osirian circuit. Mehet-Weret is called the eye of Re, associating her with Hathor ${ }^{101}$, and she is transporting the mummy of the deceased to the celestial afterlife of Re, and guarantee safe passage through the gates of the underworld. Siamun hopes for a new blessed afterlife, wishing to overcome death and enjoy eternal 
life through his assimilation with Osiris of $\mathrm{NN}^{102}$. In general, the deceased pays a great attention to Osiris, including transporting the corpse to the tomb, the funeral rituals, the purification, the mummification and then the judgment' court before Osiris, proving his jubilance and wellness to traverse to the realm of Osiris at the end of his nocturnal journey, then the second step, the deceased has to pay more care towards Re, hope to join the bark of Re to secure a successful night journey, reaching the East horizon, and achieving the solar methodology of rebirth as Khepri.

The appearance of Tithoes in this funerary bark of Tomb B7 is mainly due to his special local cult in Akhmim as the son of Isis and has a special local cult in Akhmim $^{103}$. Moreover, his protective qualities as the master of the seven demons, qualified him to protect the deceased in the solar bark in the afterlife. The upper frieze of the scene shows different demons holding their attributed knives before three edifices topped with a hkr- kheker frieze in green, the middle one is partially damaged; it symbolizes as the sign of protection which is widely depicted in the Books of the afterlife. It connects with Chapter 144 of the Book of the Dead, as well as sections of the Book of the Gates, and the imydw3t Amduat as well ${ }^{104}$. It imitates as a netherworld gate that has to be traversed by the deceased on his way to the Field of Rushes, where each gate is protected by a demon holding two knives who try to prevent him from passing ${ }^{105}$.

\begin{tabular}{|c|c|c|c|c|c|c|}
\hline Tomb & Layout & $\begin{array}{l}\text { The decead's } \\
\text { identity }\end{array}$ & Dating & $\begin{array}{l}\text { The funeral } \\
\text { 's location }\end{array}$ & $\begin{array}{l}\text { Transportation's } \\
\text { mean }\end{array}$ & $\begin{array}{l}\text { The adjacent } \\
\text { scene }\end{array}$ \\
\hline $\begin{array}{l}\text { Petosiris/ } \\
\text { Tuna El- } \\
\text { Gebel }\end{array}$ & $\begin{array}{l}\text { Two rooms: } \\
\text { the pronaos } \\
\text { and chapel }\end{array}$ & $\begin{array}{l}\text { high priest } \\
\text { of Thoth }\end{array}$ & $\begin{array}{l}\text { Early } \\
\text { Ptolemaic- } 4^{\text {th }} \\
\text { century BC }\end{array}$ & $\begin{array}{l}\text { Chapel, east } \\
\text { wall, upper } \\
\text { register }\end{array}$ & $\begin{array}{l}\text { Two wheels- } \\
\text { cart carries a } \\
\text { papyrus bark. } \\
\text { No mummy is } \\
\text { depicted. }\end{array}$ & $\begin{array}{l}\text { A big ceremony } \\
\text { includes } \\
\text { Lustration, } \\
\text { offering and } \\
\text { mourning. }\end{array}$ \\
\hline $\begin{array}{l}\text { Si Amun- } \\
\text { Siwa }\end{array}$ & Two rooms & $\begin{array}{l}\text { Priest of } \\
\text { Amun }\end{array}$ & $\begin{array}{l}\text { Ptolemaic } \\
\text { period, } 3^{\text {rd }} \\
\text { century BC, } \\
\text { reused in the } \\
\text { Roman period }\end{array}$ & $\begin{array}{l}\text { First room, } \\
\text { east wall, } \\
\text { lower } \\
\text { register }\end{array}$ & $\begin{array}{l}\text { Two wheels- } \\
\text { cart carries the } \\
\text { mummy on a } \\
\text { damaged lotus } \\
\text { bark. }\end{array}$ & $\begin{array}{l}\text { Goddess Mehet- } \\
\text { weret }\end{array}$ \\
\hline $\begin{array}{l}\text { Petubastis } \\
\text { El- } \\
\text { Mazawaka }\end{array}$ & One room & $\begin{array}{l}\text { Priest of } \\
\text { Thoth }\end{array}$ & $\begin{array}{l}\text { Roman } \\
\text { period, } \quad 1^{\text {st }} \\
\text { century AD }\end{array}$ & $\begin{array}{l}1^{\text {st }} \text { scene: the } \\
\text { east wall, } \\
\text { lower } \\
\text { register. }\end{array}$ & $\begin{array}{l}\text { Four wheels } \\
\text { cart carries the } \\
\text { mummy, and } \\
\text { without a bark. }\end{array}$ & $\begin{array}{l}\text { A big procession } \\
\text { includes } \\
\text { Petubastis sits } \\
\text { on a stool in his } \\
\text { tomb, the Four } \\
\text { Sons of Horus } \\
\text { and Anubis }\end{array}$ \\
\hline Tomb B7 & Two rooms & Unknow & $\begin{array}{l}\text { Ptolemaic } \\
\text { period }\end{array}$ & $\begin{array}{l}\text { The } \\
\text { antechamber, } \\
\text { the east wall }\end{array}$ & $\begin{array}{l}\text { Four wheels } \\
\text { cart carries the } \\
\text { mummy, and } \\
\text { with a papyrus } \\
\text { bark. }\end{array}$ & $\begin{array}{l}\text { Many demons } \\
\text { with weapons } \\
\text { for protection }\end{array}$ \\
\hline
\end{tabular}




\section{Endnote}

${ }^{1}$ R. Friedman., Predynastic Period, in: Z. Hawass (ed.), the Treasures of the Pyramids, Cairo, 2003, 60-61; id., "Hierakonopolis", in: D. Patch (ed.), Dawn of Egyptian Art, New Haven and London, 2011, 90

${ }^{2}$ F. Lankester, Desert Boats: Predynastic and Pharaonic Era Rock- Art in Egypt's Central Eastern Desert, Oxford, 2013; E. Avi- Yonah., To See the Good... Reflections on the Iconography of the Deceased Tomb in Ancient Hierakonopolis, in: Papers for Discussions 2, 7-85, 1985, 7-82, R. Friedman., The Cemeteries of Hierakonopolis, Archéo-Nil 18, 2008, 21-22, B. Midant-Reynes., The Prehistory of Egypt, Oxford, 2000, 206- 210.

3 T. Wilkinson., Genesis of the Pharaohs: Dramatic New Discoveries That Rewrite the Origins of Ancient Egypt, London, 2003, 157-158, M. Smith., Following Osiris, 21-24.

4 M. Smith, M., Following Osiris, 63-64.

5 G. Legrain, "Le logement et transport des barques sacrées et des statues des dieux dans quelques temples égyptiens", BIFAO, 1917, 1-76, Pls. I-VII, 1-13.

${ }^{6} \mathrm{~J}$. Allen, Some Aspects of the Non-Royal Afterlife in the Old Kingdom, in: M. Barta (eds.), The Old Kingdom Art and Archaeology, Prague, 2006, 10.

${ }^{7}$ E. Teeter, Religion and Ritual in Ancient Egypt, Cambridge, 2011, 121.

${ }^{8}$ J. Taylor, Death and the Afterlife in Ancient Egypt, London, 2001, 188.

${ }^{9}$ Great details of the mourning actions by the relatives of the deceased are depicted on the mummy coffin of the high priest of 'Amun Amenemope' from Thebes, dates to the $22^{\text {th }}$ dynasty. J. Taylor, Death and the Afterlife, 188-189, figs. 131-132.

10 M. Smith., Following Osiris, 77

${ }^{11}$ For more information about the scenes of pilgrimage to Abydos, and the funeral in the tombs, see, A. Eissa, the scenes and symbolism of Pilgrimage and funeral visits in the ancient Egyptian scenes and texts. Unpublished Master thesis, Cairo, 1983.

12 H. Köpp, Desert Travel and Transport in Ancient Egypt, in: Förster, F and Reimer, H (eds.), Desert Road and Archaeology in Ancient Egypt and Beyond, Köln, 2013, 112.

13 P. Creasman, and N. Doyle, Overland Boat Transportation During the Pharaonic Period: Archaeology and Iconography, in: Journal of Ancient Egyptian Interconnections, 2010, 17, figs. $8,9$.

${ }^{14}$ P. Creasman, and N. Doyle, Overland Boat Transportation During the Pharaonic Period, 17, figs. 8, 9.

15 F.W. Von Bissing, Ein thebanisher Grabfund aus dem Anfang des Neuen Reiches, Berlin, $1900,43$.

16 J. Tylor and S. Clarke, The Tomb of Sebeknekht. Wall Drawings and Monuments of El Kab, London, 1896, 1, pl. II.

17 A ceremonial cart is depicted in the pyramid causeway of Shaure at Abusir, where the king on his throne is receiving gifts, which in turn is placed on a platform besides which there is a ramp, the platform is fitted by two wheels, T. El Awady., Sahure: The Pyramid Causeway: History and Decoration Program in the Old Kingdom, Abusir 16, Prague 2009, 168-171, pl.6. The throne of Nyuserre is also equipped with wheels, L. Borchardt., Das Grabdenkmal des Königs Ne-user$\mathrm{Re}^{\mathrm{c}}$, Leipzig, 1907, 90.

18 See, A. Winkler, "Dealing about wheeling in Augustan Thebes: a demotic lease of a cart (O. Ashm.Dem. 28)", .Enchoria 35, 2016-2017, 69-94; H. Köpp, Desert Travel and Transport in 
Ancient Egypt, in: Förster, F and Reimer, H, Desert Road and Archaeology in Ancient Egypt and Beyond, Köln, 2013, 111; Reisen im Alten Ägypten: Reisekultur, Fortbewerungs und Transportmittel under besonderer Berücksichtingung des Landverkehrs, Unpublished Ph. D dissertation, Göttingen, 2006, 120-243.

19 H. Köpp, Desert Travel and Transport in Ancient Egypt, 111-112.

20 J. Vogt, Die alexandrinishen Münzen, Stutgart, 1924, 145.

${ }^{21}$ Chemmis is the land where the mother goddess Hathor take care of Horus, that Isis concealed her son Horus from Seth, Hathor protect him from god Seth in the marshes of papyrus in Chemmis; where the site of the contest between Horus and Seth. On Khemmis 'Chemmis' see: Zandee, J., "A Site of Conflict between Horus and Seth", in : Exorbe Religionum Studia Geo widengren ( ed. by Prior, P), Leiden, 1972; M. Smith., Traversing Eternity, 91, 194, 239, 595.

${ }^{22}$ On this text, see, S. Sauneron., Esna I, IFAO, Le Caire, 1959, N.184, 71; id., Esna II, IFAO, Le Caire, 1963, no. 190, 130; P. Vernus., Athribis, textes et documents relatifs à la géographie, aux cultes, et à l'histoire d'une ville du delta égyptien à l'époque pharaonique, Le Caire, 1978, Doc. 282, 311.

${ }^{23}$ The text was mentioned by Sauneron, Esna II, no. 190, 130, and it was translated by him in Esna I, N.184, 71

24 It is now in Museum der Julius Maximilians University-Würzburg, M. Stadler, Funerary Religion, the Final Phase of an Egyptian Tradition, in: the Oxford Handbook of Roman Egypt, Oxford, 2012, 383

25 A. Festugiere, Corpus Heremeticum II, Paris, 1960, 234.

26 J. Yoyotte, Bakhthis, Religions Egyptienne et cultures Grecque a Edfou, in : Religions en Egypte hellénistique et romain, Colloque de Strasbourg 16-18 Mai 1976, Annuaires de l'École pratique des hautes études Paris, 1969, 140.

27 E. Cumot, Lux Perpeuta, Paris, 1949, 292.

28 A. Delatte and P. Derchain, Les intailles magiques Greco- égyptiennes, Paris, 1964, nos. 294 ; C. Bonner, Studies in Magical Amulets, London, 1950, 140.

29 A. Delatte and P. Derchain, Les intailles magiques, nos. 295 ; E. Doriton, Le Char dans la Glyptique Egyptienne, BSFE 28-29, 1959, 17-24.

${ }^{30}$ For the Charon in the Greek mythology on Alexandrian loculos slabs, M. Venit, Visualizing the Afterlife, 81-83

31 M. Heerma Van Voss, “Fährmann”, LÄ II, 1977, 86.

32 M. Smith, Following Osiris, 370

33 W. Grajetzki, Burial Customs in Ancient Egypt: Life in Death for Rich and Poor, London, 2003, 129; G. Vittmann, "Tradition und Neuerung in der demotischen Literature”, ZÄS 125, $1998,69$.

34 AS those found in a cache of burials discovered in the forecourt of the pyramid temple of Mnkaure at Giza, S. Farid, Preliminary Report on the Excavations of the Antiquities Department at Kom Abu Billo, ASAE 61, 1973, 26; G. Vittmann, "Tradition und Neuerung in der demotlischen Literature", Z̈̈S 125, 1998, 69, note.57; W. Grajetzki, Burial Customs in Ancient Egypt: Life in Death for Rich and Poor, London, 2003, 129; S. D’Auria, P. Lacovara and C.H. Roehring , Mummies and Magic: The Funerary Arts of Ancient Egypt, Boston, 1988, 195-196

35 M. Venit, Visualizing the Afterlife in Tombs of Graeco- Roman Egypt, Cambridge, 2016, 69. 
36 J. Allen, Some Aspects of the Non-Royal Afterlife in the Old Kingdom, in: M. Barta (ed.), The Old Kingdom Art and Archaeology, Prague, 2006, 10.

37 M. Barta, Aufbau und Bedeutung der altägyptischen Opferformel, Glückstadt, 1986,10, 2729, 30; M. Smith, Following Osiris, Perspectives on the Osirian Afterlife from Four Millennia, Oxford, 2017,44-46,75-76

38 For mummification techniques in Ptolemaic- Roman Egypt see M. Smith, Traversing Eternity, Texts from the Afterlife from Ptolemaic and Roman Egypt, Oxford, 2009, 30-38

39 J. Assmann, Death and Salvation in Ancient Egypt, (translated by D. Lorton), Ithaca, NY: Cornell University Press, 2005, 308. E. Teeter, Religion and Ritual, Religion and Ritual in Ancient Egypt, Cambridge, 2011, 138

${ }^{40}$ B. Haring, Divine Households: Administrative and Economic Aspects of the New Kingdom Royal

Memorial Temples in Western Thebes. Egyptologische Uitgaven 13, Leiden, 1997, 4.

${ }^{41}$ About opening of the mouth ritual see, J. Taylor, Death and the Afterlife, 190-192

42 J. Settgast, Untersuchungen zu altägyptischen Bestattungsdarstellungen. ADAIK 3, Glückstadt, 1963, 43; G. Reeder, "The Mysterious Мuи and the Dance They Do", KMT 6, no. 3, 1995, $68-77$

${ }^{43}$ J. Taylor, Death and the Afterlife, 193, J. Assmann, Death and Salvation, 329

44 About the funeral see, E. Teeter, Religion and Ritual, 119-137

${ }^{45}$ S. Vleeming (ed.), Hundred- Gated Thebes: Acts of a Colloquium on Thebes and the Theban Area in the Graeco- Roman Period, P.L. BAT 27, Leiden, 1995, 246-248.

46 The grave-diggers were supposedly contracted by the choachytes, see U.P.Z.II $185 \mathrm{i} 6$.

47 Since the New Kingdom, He had been a perfectly respectable occupation in the early demotic period (6-5th century), about the chaoachytes care of the dead see, S. Vleeming, "The Office of a Choachyte in the Theban Area", 246-248.

48 S. Vleeming, "The Office of a Choachyte in the Theban Area", 246

49 E. Boswinkel, P. Pestman, Textes Grecs, démotiques et bilingues, P. L. Bat. 19, Leiden, 1978, 196. In Christian Egypt, it was the custom to wait for a certain period before entombing the dead in the tomb, later, by the Theodosian code of $392 \mathrm{AD}$, the pagan myths forced the residents to remove the dead from the homes and bury them immediately. D. Montserrat, The Kline of Serapis, JEA 78, 305; Willeitner, J., " Grab- und Begräbnissitten nach Alexander dem Großen, Ägypten, Die Welt der Pharaonen,, in: R. Schulz and M. Seidel (Hgg.), , Könemann, 1997, 320

${ }^{50}$ Diod. Sic. I. 92.6.

${ }^{51}$ B. Borg, The Dead as a Guest at Table? Continuity and Change in the Egyptian Cult of the Dead, in: M.L. Bierbrier (ed.), Portraits and Masks, Burial Customs in Roman Egypt, the British Museum Press, 1997, 29

${ }^{52}$ B. Borg, The Dead as a Guest at Table?, 28-29. On ancestral cult, R. Demaree., the 3h íkr n $\mathrm{R}^{\mathrm{c}}$ - Stelae. On Ancestor Worship in Ancient Egypt, Leiden, 1983.

53 B. Borg, The Dead as a Guest at Table?, 27

${ }^{54}$ D. Montserrat., "Death and Funerals in Roman Fayum", in M. L. Bierbrier (ed.), Portraits and Masks: Burial Customs in Roman Egypt, London, 1997, 38.

${ }^{55}$ P. Princ. III. 166.4-7. 
56 S. Quirke, "Mummy Labels”, in S. D‘Auria, P. Lacovara and C.H. Roehrig (eds.), Mummies and Magic: The Funerary Arts of Ancient Egypt, Boston, 1988, 229.

57 S. Vleeming, "The Office of a Choachyte in the Theban Area", 247

58 P. Oxy. III494.22-5 (165); D. Montserrat, The Kline of Serapis, JEA 78, 305; B. Borg, The Dead as a Guest at Table?, 26-32

59 K. Hopkins, Death and Renewal, Cambridge, 1983226-234. It was a typical custom in Rome itself, M. Caroll, Spirits of the Dead: Roman Funerary Commemmoration in Western Europe, Oxford, 2006, 180-186. These regular visits and funerary banquets confirm the close social connection between the dead and their relatives and friends to commemorate his or her death. P. Tebt. I.118; P. Oxy.III. 494.22.5.

60 P. Oxy. III.494.24; D. Montserrat, The Kline of Serapis, 304

61 S. Vleeming., "The Office of a Choachyte in the Theban Area", 247.

62 E. Hornunug, Vom Sinn der Mummifizierung, Die Welt des Orients 14, 1983, 167-175

63 J. Richards, Society and Death in Ancient Egypt: Mortuary Landscapes of the Middle Kingdom, Cambridge, 2005, 56.

64 K. Parlasca, Mumienporträts und verwandte Denkmäler, Wiesbaden 1966, 159-160,taf.58.2; L. Kakosy, Bark and Chariot, in: Stu. Aeg.III,57-63.

65 Plutarch, De Iside, 34.

66 W. Till, Koptisch- gnostische Schriften, BD. I, Berlin, 1962, 233 (Cap. 136), L. Kakosy, Bark and Chariot, 62

${ }^{67}$ Lefebvre suggested that Petosiris' death ca. 285 BC, Lefebvre, G., "Le Tombeau de Petosiris, Vol. I, Cairo, 1923-1924, 12. Bissing suggested earlier date (305 BC), Von Bissing, F., Die Dateriung die griechish- ägyptische Grabes von Mellaui, OLZ 26, 1923, cols. 2-4. Picard supposed a Persian date, Picard, C., "Les influences étrangères au tombeau de Petosiris: Grèce ou Perse?", 1931, BIFAO 30, 201-204. Menu argued that Petosiris was the priest of Thot during Alexander the Great, Menu, B., "La Tombeau de Petosiris, nouvel examen", BIFAO 94, 1994, 311-327.

${ }^{68}$ Bevan suggested that Petosiris acted as the high priest of Thoth under Nectanebo and Ptolemy I Soter, E. Bevan., A History of Egypt under the Ptolemaic Dynasty, London, 1927, 81

69 G. Lefebvre, "Le Tombeau de Petosiris, 134-135; M. Venit, Visualizing the afterlife, 12-13, Fig. 1.4; K. Dittmann, Der Segelwagen von Medinet Madi, MDAIK 10,1940, 68-69, abb.7

${ }^{70}$ K. Dittmann, MDAIK 10, 69, abb.8; J. Wilkinson, Manners and Customs of the Ancient Egyptians : Including their Private Life, Government, Laws, Art, Manufactures, Religion, and Early History. /Vol. II, Cambridge, 1837, 341.

71 P. Creasman, and N. Doyle, Overland Boat Transportation, 17

72 Vandierd'Abbadie, Deux Tombes ramessides a Gournet-Mourrai, MIFAO 87, Le Caire, 1954, pl. VIII, X;

G. Foucart, Le tombeau d'Amonmos(tombeau no.19), MIFAO 57,3, 1932,37, fig.5, pl.IV,9.

73 For example,Vandier d'Abbadie 1954, pl. X (TT277); E. Naville, Das aegyptische Todtenbuch der XVIII. bis XX. Dynastie, Vol. I, Berlin, 1971,taf.III.P.e.

${ }^{74}$ For exemple, M. Baud and É. Drioton, Le tombeau de Roÿ (tombeau no. 255) , MIFAO 57,1,1928, fig.7; Naville1971,taf.III.P.j.,L.e

75 For example, TT78 :V. Annelies and A. Brack, Das Grab des Haremheb: Theben nr. 78 , AV 35, Mainz am Rhein, 1980,Taf.16,55b ; TT16: M. Baud and É. Drioton, Le tombeau de 
Panehsy, "tombeau no. 16" in Georges Foucart, M. Baud, and E. Drioton (eds.), Tombes Thébaines: Nécropole de Dirâ' Abû'nNaga: Le tombeau de Roÿ 'tombeau no. 255'; Le tombeau d'Amonmos 'tombeau no. 19'; Le tombeau d'Amon-am-anit 'tombeau no. 277', Cairo:IFAO,1935, Pl.2,11, fig.3.

76 For example, TT19, Foucart, Le Tombeau d'Amonmos, 37, fig.5, Pl. IV

77 For example, TT255, N. Davies, “An Apparent Instance of Perspectival Drawing”, JEA 11, 1926, 110-112; M. Lichtheim, Situla No. 11395 and Some Remarks on Egyptian Situlae, JNES 6.3, 1947, 169-179.

${ }^{78}$ A. Fakhry., 1944, 134

79 K. Lembke, Fluck, C and G. Vittman., Ägyptens späte Blüte:Die Römer am Nil, Mainz, 2004, 70.

${ }^{80}$ M. Venit., Visulaizing the Afterlife, 136.

81 Lloyd suggested a Greek ethnic of Siamun, A. Lloyd, Book II", in: O. Murray and A. Moreno (eds.), A Contemporary on Herodotus. Books I-IV, Oxford, 2007, 225.

82 M. Venit, Visualizing the Afterlife, 136, for more information, see, L. Lembke, Ammoniaca II, Das Grab des Siamun in Der Oase Siwa (with Contributions by H. Fellber and J. Moje, M. Sohn and M. Al- Roumi), AV 115, Wiesbaden, 2015.

83 A. Fakhry, The Egyptian Deserts. Siwa Oasis. Its History and Antiquities, Cairo, 1944, 145, A. Fakhry, Siwa Oasis, Cairo, American University in Cairo Press, Vol. I, 1990, 194-195, 197198, fig.74.

${ }^{84}$ El-Mazawaka, was the Roman cemetry of the city Trimithis (modern Amheida), it means “ the decorative hill", and it contains a series of ridges with more than more 200 tombs of Roman period, most of these tombs were looted and destroyed, Venit, Visualizing the Afterlife, 157.

85 J. Osing., Denkmäler der Oase Dachla, aus dem Nachlass von A. Fakhry, AV 28, Mainz, $1982,71$.

${ }^{86}$ M. Venit., Visulaizing the Afterlife, 158.

87 Osing dates the tomb to the $1^{\text {st }}$ century AD, based on two Demotic graffiti on the north wall of the chamber, J. Osing, Denkmäler der Oase Dachla, aus dem Nachlass von A. Fakhry, AV 28, Mainz, 1982, 71. the four spoked-wheeled carts was known in Egypt since the 18th Dynasty as the model wagon in the tomb of Ahhotep, F. Von Bissing, Ein Tebanischer Grabfund aus dem anfang des neuen reichs. Neudruck der Ausgabe, 1900, taf. X. It still in use during Late Periods according to Herodotus' description of a special festival from the Persian period that took place in Papremis of a religious drama shows a statue of a god was transported by a four-wheeled carriage, Herodotus, II, 63.

88 J. Osing, Denkmäler der Oase Dachla, 75, tab. 21 d; M. Venit, Visualizing the Afterlife, 160.

${ }^{89}$ M. Venit, Visualizing the Afterlife, 123.

90 El-Salamuni Mountain located $6 \mathrm{~km}$ east of Akhmim. Its name is derived from the modern village located on the foot of the archeological mountain. A rock-cut temple for god Min locates on the uppermost top of the mountain. At the foot of this mountain is "El-Isawieh" canal.

${ }^{91}$ Akhmim lies on the east bank of Sohag. During the Graeco- Roman period, Akhmim was known as Panopolis, and it was the metropolis ' capital' of the $9^{\text {th }}$ nome of Upper Egypt, the panopolite nome, M. Venit., Visualizing the Afterlife, 182-183. On El-Salamuni Tombs, see, N. Kanawati., Sohag in Upper Egypt, A Glorious History ,Prism Archaeological Series 4, Gizeh, 1990, pls. 40-42; K. Kuhlmann.,'Materialien zur Archäologie und Geschichte des Raumes von 
Achmim', SDAIK 11, Mainz, 1983, 71-86, pls. 27-38; I. Kaplan., (1999), Grabmalerei und Grabreliefs der Römerzeit, Wechselwirkung zwischen der Ägyptischen und GriechischAlexandrinischen Kunst (BzA16, Vienna), 1999, 171-177, pl. 90 a, b, 91 a, b, 93 b, 94 a, b, 95 a, b, 98 b, 99b, 100 a, b; C. . Riggs, the Beautiful Burial in Roman Egypt, Art, Identity, and Funerary Religion, Oxford, 2005, 164-165

92 M. Stadler, Skarabäus als Osirianisches Symbol, ZÄS 128, 2001, 79, Abb.1, it is also depicted on a mummy coffin from Deir el-Medineh, B. Bruyere., Rapport sur les fouilles de Deir el-Medineh, Annees 1948 a 1951, FIFAO 26, Le Caire, 1953, taf. 24.

93 As the Dublin shroud of Hawara, which is now in the National Museum of Ireland, it dates back to mid of the $1^{\text {st }}$ century AD, C. Riggs, the Beautiful Burial, 29-31, figs 5,6.

${ }^{94}$ Rössler-Köhler, U., "Löwe”, in LÄ III, 1085-1086; Schweitzer, U., Löwe und Sphinx im Alten Ägypten, ÄF 15, Gluckstadt and Hamburg, 1984. The lion's bier first depicted in the tomb of Sennedjem at Deir el-Medina, I. Kaplan, Grabmalerei und Grabreliefs, 25, fig. 1 a.

95 K. Goebs., 'Crowns', in D. B. Redford (ed.), The Oxford Encyclopedia of Ancient Egypt, I, Oxford, 322.

96 F. Dunand and C. Zivie- Coche, "Dieux et Hommes en Egypte, 3000av J.C-395 apr. J.C“, Anthropologie religieuse, Paris, 1991, 29-30.

97 As depicted on a relief from the temple of northern Athribis. O. Kaper, The God Tutu (Tithoes) and his Temple in the Dakhla Oasis, BCAE 2, 1991, 60, 63-64, figs. 2, 4.

98 D. Frankfurter, Religion in Roman Period, Assimilation and Resistance, Princeton, 1998, 115.

99 Tithoes is also considered as an oracle god in Ptolemaic-Roman period, J. Quaegebeur, "Tithoes, Dieu Oraculaire", Enchoria 7, 1977, 103-108. He was a familiar god in the Hellenistic Egypt, J. Quaegebeur, "Cultes égyptiens et grecs En Egypte Hélenistique, Exploitation des Sources", in : V. T'Dack et al (ed.), Egypt and The Hellenistic World, Proceeding of The International Colloquium, Leuven 24-26 May 1982,), Studia Hellenistica 27, Leuven, 1983, 308-310, fig.2; U. Wilcken, Archive für Papyrus Forschun 2, 1903, 180, W. Spiegelberg, Ägyptische und Etiketten der Römischen Kaiserzeit, Leipzig, 1901,46.

100 J. Osing, Denkmäler der Oase Dachla, 85, 89, tafs. 25 a, and 27d.

101 As depicted in Vignette BD 17, R. Wilkinson, 2003, 174.

102 On the Osiris NN concept, M. Smith., Osiris NN or Osiris of NN, in B. Backes, I. Munro and S. Stöhr (eds.), Totenbuch-Forschungen: Gesammelte Beiträge des 2. Internationalen TotenbuchSymposiums, Bonn 25. Bis 29. September 2005, Wiesbaden, 2006, 325-337.

103 P. Munro., Die Spätägyptischen Toten-Stelen, Ägyptologische Forschungen 25, Glückstadt, 1973, 320; G. Maspero., Sarcophages des époques persans et Ptolemaique, CGC, Vol. II, Cairo, 1939; O. Kaper., The Egyptian God Tutu, A Study of the Sphinx-God and Master of Demons with a Corpus of Monuments, OLA 119, Leuven, 2003; S. Sauneron., "Le Nouveau Sphinx Composite du Brooklyn Museum et le Role di Dieu Touton-Thithos ", in: JNES 9,1960, .269-287.

${ }^{104}$ E. Hornung, the Ancient Egyptian Books of the Afterlife, Ithaca, 1999, 57-58

105 As depicted in Chapter 145 of the Book of the Dead. J. Osing, Denkmäler der Oase Dachla, 77, S. Quirk, Going out in Daylight, Prt $m$ hrw, the Ancient Egyptian Book of the Dead, Translation, Sources, Meaning, London, 2013, 330-331. 


\section{هبالة اتماد الجامعات المربية السيامة والصيانة}

\section{(JAAUTH)}

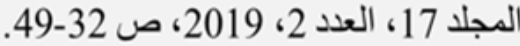

http://jaauth.journals.ekb.eg الموقع الإلكتروني،

نقل المتوفى بواسطة العربة ذات العجلات في مقابر العصر اليوناني- الروماني

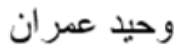

قسم الإرشاد السياحي، كلية السياحة و الفنادق، جامعة الفيوم.

تشمل الورقه البحثيه عملية نقل مومياء المتوفى إلى المقبره خلال العصر اليوناني- الروماني

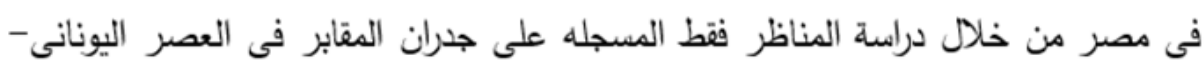

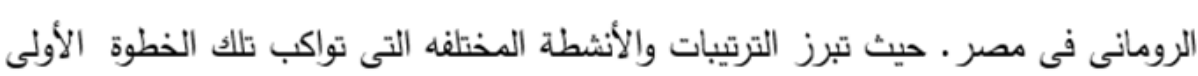

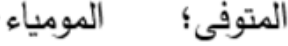

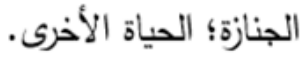
المهمة للمتوفى فى إطار إثبات بعثه فى العالم الأخر . تعتبر العربة ذات العجلات الوسيلة

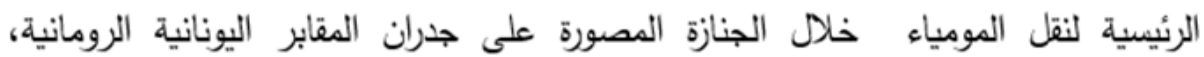

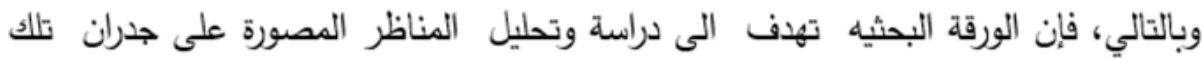
المقابر والطراز المميز لعربة نقل مومياء المتوفى.

\section{(JAAUTH)} المجلد 17، العدد 2، (2019) ص 49-32. 